\title{
ANALISIS KEJADIAN EL NINO TAHUN 2015 DAN PENGARUHNYA TERHADAP PENINGKATAN TITIK API DI WILAYAH SUMATERA DAN KALIMANTAN
}

\author{
Analysis of the 2015 El Nino Event and Its Influence on the Increase of \\ Hotspots in Sumatera and Kalimantan
}

\author{
Ardila Yananto ${ }^{1)^{*}}$, Saraswati Dewi $i^{2)}$ \\ ${ }^{1,2)}$ Balai Besar Teknologi Modifikasi Cuaca - Badan Pengkajian dan Penerapan Teknologi, Gedung Ir. \\ Mohammad Soebagio, GEOSTECH (820), Kawasan PUSPIPTEK, Serpong, Tangerang Selatan \\ *E-mail : ardila.yananto@bppt.go.id
}

\begin{abstract}
Intisari
Kejadian El Nino yang berdampak pada sebagian besar wilayah Indonesia akan selalu berasosiasi dengan kekeringan akibat dari berkurangnya intensitas curah hujan. Lebih jauh akibat dari kekeringan tersebut telah menimbulkan meningkatnya titik api secara signifikan dibandingkan dengan tahun-tahun sebelumnya khususnya di wilayah Sumatera dan Kalimantan, dimana hal tersebut telah mengakibatkan terjadinya bencana asap pada tahun 2015. Tujuan utama penulisan karya tulis ini adalah untuk menganalisis kejadian El Nino pada tahun 2015 dan pengaruhnya terhadap peningkatan titik api di wilayah Sumatera dan Kalimantan baik dalam skala temporal maupun spasial. Dari hasil penelitian ini dapat diketahui bahwa berdasarkan parameter NINO 3.4 SST Indeks dan Southern Oscillation Index (SOI) pada tahun 2015 telah terjadi fenomana EI Nino pada level kuat yang ditandai dengan adanya pelemahan sirkulasi walker sehingga pusat tekanan rendah perpindah dari Samudera Pasifik bagian Barat ke Samudera Pasifik bagian Timur, dimana hal ini telah menyebabkan adanya penurunan intensitas curah hujan (anomali negatif) disebagian besar wilayah Indonesia terutama pada bulan Juli hingga Oktober 2015 dan oleh karena itulah pada bulan Juli hingga Oktober 2015 tersebut terjadi peningkatan jumlah titik api yang sangat tajam di wilayah Indonesia dimana persebaran titik api tersebut sebagian besar terkonsentrasi di Provinsi Sumatera Selatan dan Kalimantan Tengah.
\end{abstract}

Kata Kunci : El Nino, Suhu Permukaan Laut, Zonal Wind, Anomali Curah Hujan, Titik Api.

\begin{abstract}
El Nino that impact most areas of Indonesia will always be associated in drought due to reduced rainfall intensity. Drought, in further, has resulted in increasing titik apis significantly compared to previous years, especially in the Sumatra and Kalimantan, that was creating smog disaster in 2015. The main objective of this research was to analyze the occurrence of El Nino in 2015 and its influence on increase of titik api in Sumatera and Kalimantan both in temporal and spatial scale. From this research it is known that based on the NINO 3.4 SST index and the Southern Oscillation Index (SOI) it is known there was a strong El Niño event occurred in 2015 showed there was a weakening Walker circulation so that the low pressure center moved from Western part of the Pacific Ocean to the Eastern Pacific Ocean, where this has led to a decrease rainfall intensity (negative anomaly) in most parts of Indonesia, especially from July to October 2015 and because of that from July to October 2015 there was very hight increasing number of titik apis in Indonesia where the spread of titik api the mostly concentrated in the province of South Sumatera and Central Kalimantan.
\end{abstract}

Keywords : El Nino, Sea Surface Temperature, Zonal Wind, Rainfall Anomaly, Hotspot.

\section{PENDAHULUAN}

Sebagai negara kepulauan yang terletak di antara samudera Hindia dan Samudera Pasifik, curah hujan di Indonesia sangat dipengarui oleh perubahan suhu permukaan laut disekelilingnya. Ketika terjadi peningkatan suhu permukaan laut di bagian Tengah dan Timur Samudera Pasifik sekitar equator yang dikenal dengan EI Nino, hal tersebut berhubungan dengan penurunan curah hujan di Indonesia. Begitu juga sebaliknya ketika terjadi penurunan suhu permukaan laut di bagian Tengah dan Timur Samudera Pasifik sekitar equator atau yang lebih dikenal dengan La Nina berhubungan dengan peningkatan curah hujan di Indonesia (Mulyana, 2002). 
El Nino secara ilmiah diartikan sebagai fenomena global dari sistem interaksi laut dan atmosfer yang ditandai dengan meningkatnya suhu muka laut atau SST (Sea Surface Temperature) di sekitar Pasifik Tengah dan Timur sepanjang equator dari nilai rata-ratanya. Pada tahun - tahun normal, suhu muka laut di sebelah Utara dan Timur Laut Australia bernilai $\geq 28^{\circ} \mathrm{C}$ sedangkan suhu muka laut di Samudera Pasifik sekitar Amerika Selatan bernilai $\pm 20^{\circ} \mathrm{C}$ (Tongkukut, 2011). Dalam kondisi normal tersebut, angin equatorial berhembus ke arah barat membantu proses konveksi di Pasifik Barat dan subsidensi di Pasifik Timur.
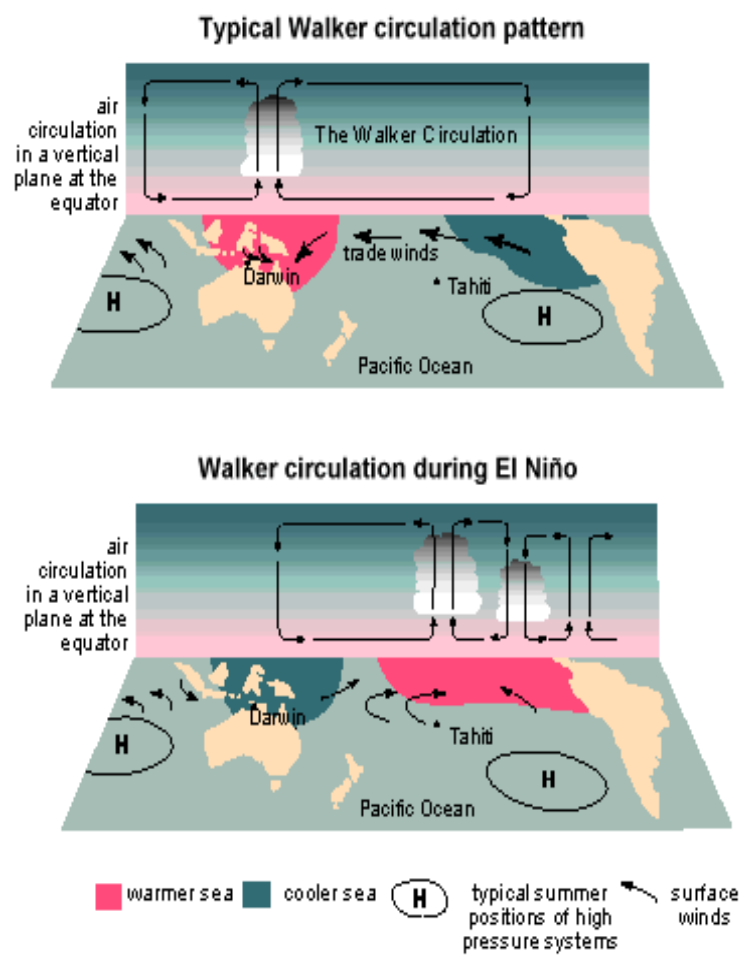

Gambar 1. Pola Sirkulasi Walker pada keadaan normal (atas) dan keadaan El Nino (bawah).

Sel sirkulasi vertikal tersebut disebut sebagai sirkulasi Walker (Gambar 1 bagian atas), dimana terjadi gerak naik di bagian Barat dan turun di Timur Samudera Pasifik Tropis dengan pergerakan ke arah Timur di Troposfer atas.

Perubahan kecil pada pola normal suhu permukaan laut di Samudera Pasifik Tropis bagian Barat akan menyebabkan perubahan angin musiman permukaan laut ke arah Timuran sepanjang equator. Perubahan angin biasanya terlihat sebagai anomali baratan yang menguatkan pertumbuhan anomali suhu permukaan laut dan angin kemudian akan merambat ke arah Timur untuk meningkatkan kondisi El Nino. Selama fase dewasa El Nino, anomali sirkulasi Warker muncul berlawanan dengan kondisi normalnya, konveksi di bagian Barat ditekan dan konveksi dibagian Timur menguat (Gambar 1 bagian bawah).
Setelah konveksi menurun di Samudera Pasifik Tropis bagian Barat, El Nino akan menyebabkan kondisi yang lebih kering di wilayah Indonesia pada umumnya (Fadholi, 2013). Pada saat kejadian Dipole Mode (DM) positif dan terjadi El Nino akan menyebabkan bergesernya sistem sirkulasi zonal yang menjauhi wilayah Indonesia ke arah Samudera Pasifik bagian tengah karena pengaruh EI Nino dan ke arah barat Samudera India karena pengaruh DM positif. Proses dinamika aliran massa uap air ini mengalami anomali mengakibatkan penurunan curah hujan di sebagian besar wilayah Indonesia bagian selatan ekuator (Harijono, 2008).

Pengaruh fenomena El Nino/IOD (+) adalah penurunan jumlah curah hujan tahunan dan musiman terutama Juni-Juli-Agustus (JJA) dan September-Oktober-November (SON) baik untuk tipe hujan monsunal maupun tipe hujan ekuatorial. Sebaliknya La Nina dan IOD (-) menyebabkan kenaikan jumlah curah hujan (Tjasyono, 2008). Dampak dari fenomena El Nino bagi sebagian besar wilayah Indonesia selalu berasosiasi dengan bencana kekeringan akibat berkurangnya intensitas curah hujan. Oleh karena hal tersebut pada bulan Februari 2015 di wilayah Provinsi Riau pada khususnya dan wilayah Sumatera dan Kalimantan pada umumnya sudah mulai banyak muncul titik api dari peristiwa kebakaran lahan dan hutan yang memicu terjadinya bencana kabut asap.

Kebakaran hutan di Indonesia selalu terjadi pada musim kemarau, yaitu pada bulan Agustus, September, dan Oktober, atau pada masa peralihan (transisi). Wilayah hutan di Indonesia yang berpotensi terbakar antara lain di Pulau Sumatera (Riau, Jambi, Sumut, dan Sumsel) dan di Pulau Kalimantan (Kalbar, Kaltim, dan Kalsel) (Bahri, 2002).

Dalam tulisan ini akan dianalisis faktorfaktor penyebab kejadian El Nino tahun 2015 serta untuk mengetahui pengaruh dari kejadian El Nino tersebut terhadap peningkatan titik api di wilayah Sumatera dan Kalimantan dari aspek spasial dan temporal.

\section{METODE}

Daerah kajian pada penelitian ini adalah negara Indonesia khususnya wilayah Sumatera dan Kalimantan, dimana wilayah ini identik dengan kejadian kebakaran lahan dan hutan untuk setiap tahunnya. Data yang digunakan pada penelitian ini meliputi data curah hujan bulanan dari tahun 1998-2016 dari satelit TRMM (Tropical Rainfall Measuring Mission) 3B43v7 yang didapat dari situs NASA Giovanni dengan resolusi spasial $0.25^{\circ}$, Indek anomali Kejadian El Nino berupa NINO3.4 SST Index, Southern Oscillation Index (SOI) serta Indian Ocean Dipole (IOD) tahun 2015 yang didapat dari Badan 
Meteorologi Australia (BoM), data peta SST (Sea Surface Temperature) wilayah Samudera Pasifik Tropis yang didapat dari Jet Propulsion Laboratory (JPL) NASA dengan resolusi spasial $1 \mathrm{~km}$, data gradien wind wilayah Samudera Pasifik Tropis yang juga didapatkan dari situs NASA Giovanni, dan juga data titik api berdasarkan citra satelit MODIS yang didapat dari situs LAPAN (Lembaga Antariksa dan Penerbangan Indonesia).

Analisis kejadian El Nino Tahun 2015 dilakukan dengan menganalisis nilai indeks $\mathrm{El}$ Nino berupa NINO3.4 SST Index, SOI serta IOD dan juga dengan menganalisis pola sebaran suhu permukaan laut dan gradient wind di Samudera Pasifik Tropis dari bulan Januari hingga Desember 2015.

Selanjutnya dilakukan analisis keterkaitan antara nilai indeks El Nino NINO 3.4 dengan intensitas curah hujan aktual bulanan pada tahun 2015 khusunya untuk wilayah Sumatera dan Kalimantan, Indonesia. Sedangkan analisis titik api akan dilakukan dengan membandingkan sebaran titik api baik dari aspek spasial dan temporal pada tahun 2015 di wilayah Sumatera dan Kalimantan dengan titik api periode 10 tahun sebelumnya.

\section{HASIL DAN PEMBAHASAN}

\subsection{Sea Surface Temperature dan Nino 3.4 SST Index}

Sea Surface Temperature (SST) di perairan Indonesia merupakan indeks banyaknya uap air pembentuk awan di atmosfer. Jika suhu muka laut dingin, uap air di atmosfer menjadi berkurang, sebaliknya jika suhu muka laut panas akan ada banyak uap air di atmosfer. Pola suhu muka laut di Indonesia secara umum mengikuti gerak tahunan matahari.

Suhu muka laut Samudra Hindia mempunyai rentang perubahan yang cukup lebar yaitu minimum berkisar $26.0^{\circ} \mathrm{C}$ pada bulan Agustus dan maksimum berkisar $31.5^{\circ} \mathrm{C}$ pada bulan Februari hingga Maret. Sedangkan wilayah perairan lainnya di Indonesia umumnya mempunyai rentang perubahan lebih sempit yaitu berkisar $29^{\circ} \mathrm{C}$ hingga $31.5^{\circ} \mathrm{C}$ dan waktu terjadinya suhu muka laut minimal dan maksimal tidak sama di setiap perairan (Ardhitama, 2015).

Dari berbagai hasil penelitian diketahui bahwa suhu permukaan laut ini memiliki keterkaitan dengan kejadian curah hujan. Hubungan curah hujan Indonesia dengan suhu permukaan laut global sudah banyak diketahui, tetapi keterkaitannya dengan suhu permukaan laut wilayah Indonesia belum banyak mendapat perhatian, terutama untuk curah hujan pada cakupan yang lebih sempit (Estiningtyas et al., 2007).

Dalam fenomena global NINO 3.4 SST
Index digunakan untuk sebagai salah satu indikator untuk menunjukkan akan terjadinya ENSO (El Nino/ La Nina). Dimana NINO 3.4 SST Index ini merujuk pada besar perubaan/ anomali suhu muka laut di kawasan pasifik tengah dari nilai rata-ratanya dalam kurun waktu jangka panjang. Berikut tabel klasifikasi nilai NINO 3.4 SST indek untuk pendugaan terjadinya ENSO (EL Nino/ La Nina) :

Tabel 1. Prediksi El Nino dan La Nina berdasarkan NINO 3.4 SST Index.

\begin{tabular}{|l|l|}
\hline \multicolumn{1}{|c|}{ NINO 3.4 SST Index } & \multicolumn{1}{c|}{ Fenomena } \\
\hline$>+1.5^{\circ} \mathrm{C}$ & El Nino Kuat \\
\hline$+1.0^{\circ} \mathrm{C}$ s.d $+1.5^{\circ} \mathrm{C}$ & El Nino Sedang \\
\hline$+0.5^{\circ} \mathrm{C} s . \mathrm{d}+1.0^{\circ} \mathrm{C}$ & El Nino Lemah \\
\hline$-0.5^{\circ} \mathrm{C}$ s.d $+0.5^{\circ} \mathrm{C}$ & Netral \\
\hline$-1.0^{\circ} \mathrm{C}$ s.d $-0.5^{\circ} \mathrm{C}$ & La Nina Lemah \\
\hline$-1.5^{\circ} \mathrm{C}$ s.d $-1.0^{\circ} \mathrm{C}$ & La Nina Sedang \\
\hline$<-1.5^{\circ} \mathrm{C} \quad$ La Nina Kuat \\
\hline \multicolumn{2}{|c|}{ Sumber : BMKG Indonesia } \\
\hline
\end{tabular}

Grafik data NINO 3.4 SST Index dari Januari, 2010 hingga April, 2016 yang didapat dari Bureau of Meteorology (BoM) direpresentasikan pada Gambar 2. Berdasarkan Grafik NINO 3.4 SST Index 2010-2016 tersebut dapat diketahui bahwa pada tahun 2015 telah terjadi fenomena El Nino kuat dari bulan Juli 2015 dan bahkan baru mulai menurun pada level El Nino sedang pada bulan April 2016. Rentang nilai NINO 3.4 SST indeksnya pada level kuat berkisar antara 1.6 hingga 2.95, dimana nilai indeks NINO 3.4 terkuatnya pada bulan November 2015.

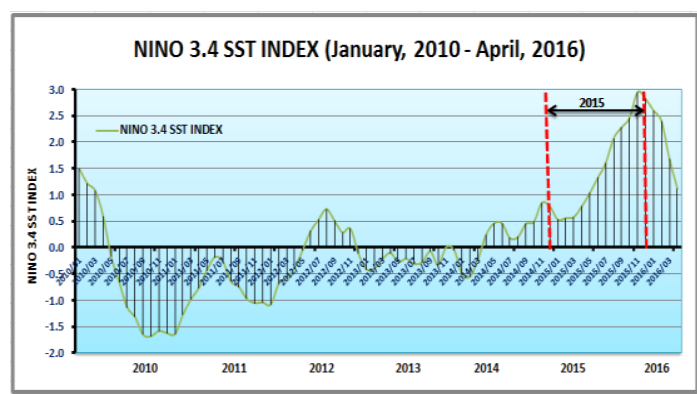

Gambar 2. Grafik NINO 3.4 SST Index (Januari 2010 - April 2016).

Analisis kejadian El Nino juga dapat dilakukan melalui peta suhu permukaan laut perairan Indonesia, Samudera Pasifik dan Samudera Hindia dari Bulan Januari hingga Desember 2015 yang direpresentasikan pada Gambar 3. Berdasarkan peta suhu permukaan laut tersebut dapat diketahui bahwa telah terjadi anomali suhu permukaan laut sejak awal tahun 2015, dimana sebagian besar Samudera Pasifik bagian tengah memiliki nilai SST yang lebih tinggi daripada SST di Samudera Pasifik bagian Barat dan juga perairan laut Indonesia. 

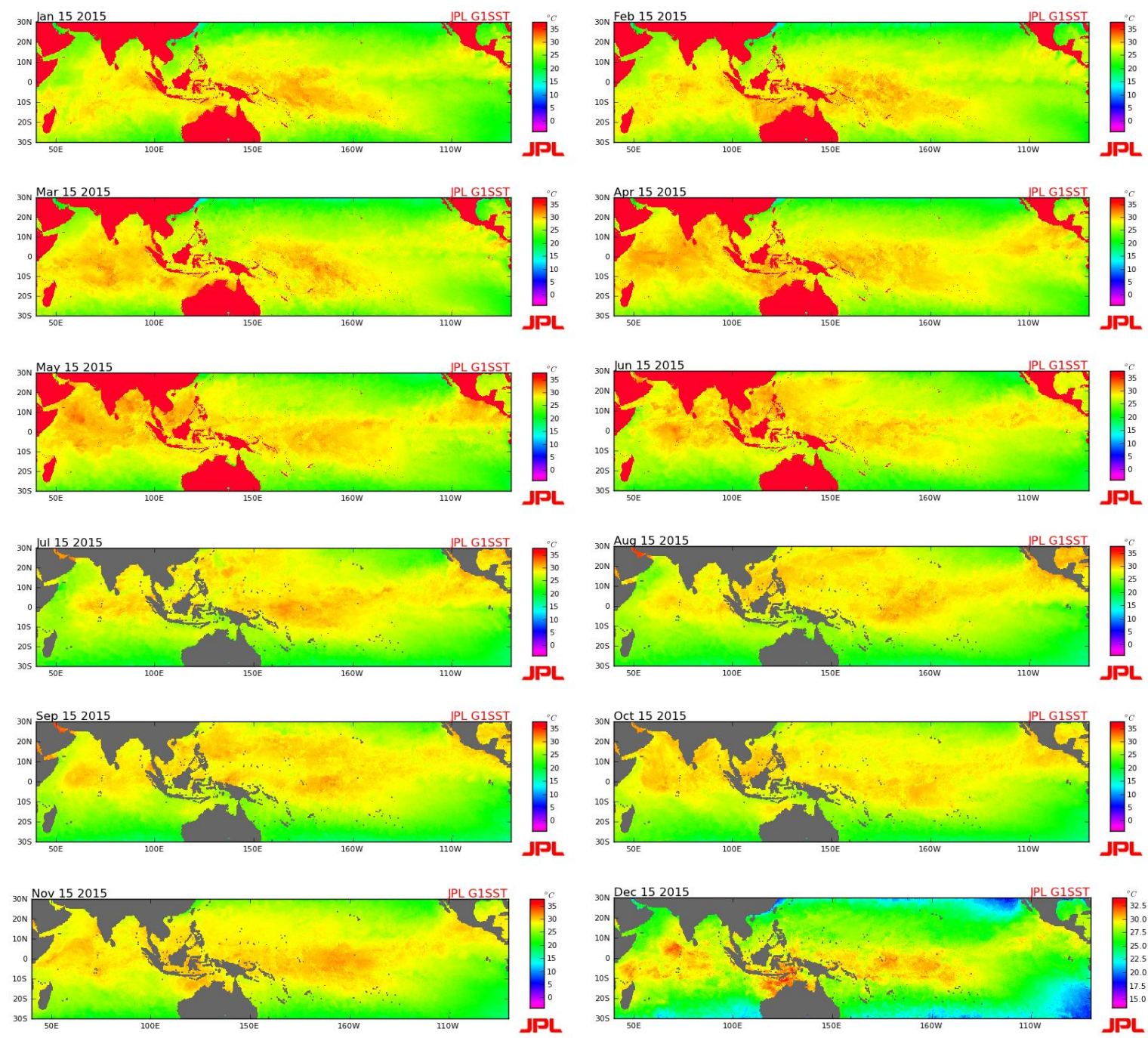

Gambar 3. Peta suhu permukaan laut wilayah perairan Indonesia, Samudra Pasifik dan Samudra Hindia bulan Januari - Desember 2015.

Dari Gambar 3 tersebut dapat diketahui juga bahwa dari Bulan Januari hingga Juni 2015 di Sebagian perairan laut Indonesia dan di Samudera Hindia Bagian Timur memiliki nilai SST yang relatif masih cukup tinggi walaupun pada luasan yang terbatas, sehingga dari Bulan Januari hingga Juni masih dimungkinkan adanya pertumbuhan awan-awan yang mengakibatkan turunnya hujan di sebagian wilayah Indonesia. Akan tetapi dari bulan Juli hingga Oktober 2015 nilai SST di perairan laut Indonesia dan di Samudera Hindia bagian Timur sebagian besar relatif lebih kecil daripada nilai SST di Samudera Pasifik Tengah, sehingga sebagian besar wilayah Indonesia dari Bulan Juli hingga Oktober 2015 curah hujannya sangat kecil atau bahkan tidak ada hujan sama sekali. Kondisi inilah yang menjadi faktor utama penyebab kekeringan yang perkepanjangan di sebagian besar wilayah Indonesia dan juga peningkatan titik api yang sangat drastis pada Tahun 2015 terutama pada bulan Juli hingga Oktober 2015. Sedangkan pada bulan November dan Desember 2015 walaupun anomali SST di Samudera Pasifik bagian Tengah
(NINO 3.4) ada pada puncak tertingginya, akan tetapi suhu permukaan laut di sebagian besar perairan laut Indonesia sudah mulai meningkat sehingga memicu adanya pertumbuhan awan yang menyebabkan turunnya hujan dengan intensitas sedang hingga tinggi di sebagian besar wilayah Indonesia.

\subsection{Southern Oscillation Index (SOI)}

Southern Oscillation Index (SOI) juga merupakan salah satu indeks ENSO (EI Nino/ La Nina) dengan melihat perubahan anomali SLP (Sea Level Pressure) di Tahiti dan di Darwin. Ketika SOI positif (+) merupakan indikasi terjadinya La Nina, tandanya SLP di daerah sekitar Darwin berada lebih rendah daripada normalnya, sedangkan di Tahiti SLP nya lebih tinggi dibanding normalnya sehingga gerakan Timuran akan menguat dan membuat kolam panas mengumpul di Darwin. Sedangkan ketika SOI negatif (-) merupakan indikasi terjadinya El Nino, dimana kondisi SLP di Darwin lebih besar dibandingkan normalnya, sedangkan SLP di daerah Tahiti lebih rendah dibanding normalnya 
sehingga dikarenakan hal tersebut gerakan timuran akan melemah dan akan mendukung kolam panas mengumpul di sekitar derah Tahiti. Berikut merupakan tabel klasifikasi nilai Southern Oscillation Index untuk pendugaan terjadinya ENSO :

Tabel 2. Prediksi El Nino and La Nina berdasarkan Southern Oscillation Index (SOI).

\begin{tabular}{|l|l|}
\multicolumn{1}{|c|}{ SOI } & \multicolumn{1}{c|}{ Fenomena } \\
\hline$<-10$ & El Nino Kuat \\
\hline-10 s.d -5 & El Nino Lemah-Sedang \\
\hline$-5 s . d+5$ & Netral \\
\hline$+5 s . d+10$ & La Nina Lemang-Sedang \\
\hline$>+10$ & La Nina Kuat \\
\hline \multicolumn{2}{|c|}{ Sumber : BMKG Indonesia }
\end{tabular}

Data Southern Oscillation Index (SOI) dari Januari, 2010 hingga April 2016 yang didapat dari Bureau of Meteorology (BoM) direpresentasikan pada Gambar 4. Berdasarkan Grafik SOI tersebut dapat diketahui bahwa selama Tahun 2015 bahkan hingga awal Tahun 2016 nilai SOI relatif bernilai minus. SOI tersebut konstan bernilai $<-10$ dari bulan Mei hingga Bulan Oktober 2015, dimana nilai SOI yang terendah ada pada bulan Oktober 2015 dengan nilai SOI sebesar -20.2. Jadi berdasarkan SOI tersebut dapat diketahui dari bulan Mei hingga Oktober 2015 telah terjadi El Nino pada level kuat.

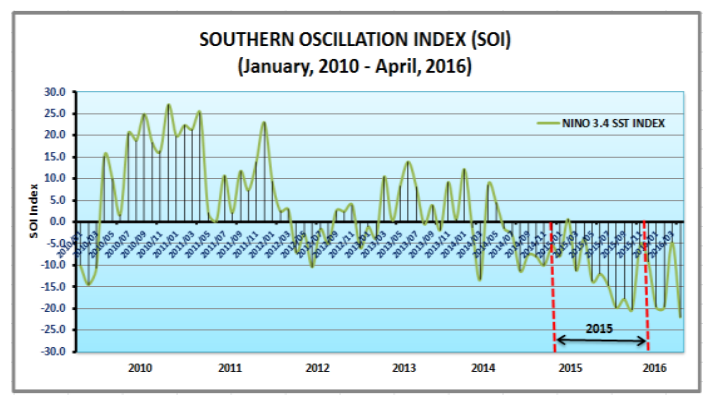

Gambar 4. Grafik Southern Oscillation Index (Januari 2010 - April 2016).

\subsection{Zonal Wind}

Salah satu parameter yang mengindikasikan terjadinya ENSO adalah melemahnya sirkulasi Walker. Sirkulasi Walker yang merupakan sirkulasi udara dari Timur ke Barat berlangsung sepanjang tahun. Saat terjadi El-Nino, pusat tekanan rendah berpindah ke Samudera Pasifik bagian Timur yaitu di sekitar Peru, hal ini menyebabkan menguatnya angin baratan. Menguatnya angin baratan selama periode ENSO dapat dilihat dari analisis angin zonal. Dalam kajian ini data yang digunakan adalah data angin zonal yang diperoleh dari http://www.esrl.noaa.gov/psd/data/gridded/data.n cep.reanalysis2.html dengan resolusi spasial $2.5^{\circ}$ $x 2.5^{\circ}$ dan resolusi temporal bulanan.
Perubahan angin zonal pada periode ENSO diperlihatkan diagram Hovmoller pada Gambar 5.

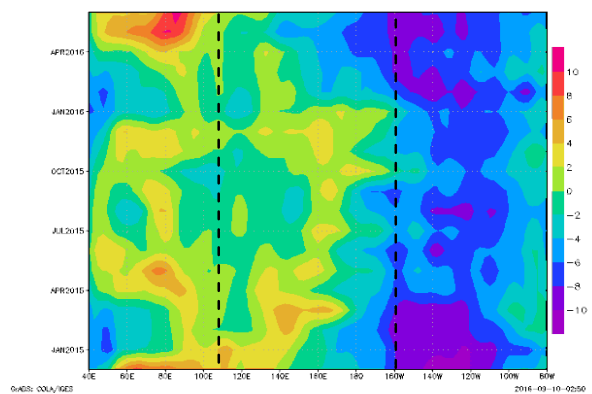

(a)

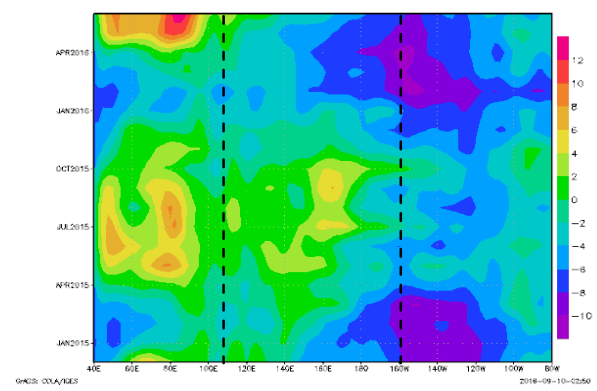

(b)

Gambar 5. Zonal Wind Analysis dari Desember 2014 hingga Juni 2016 di level $850 \mathrm{mb}$ di latitude $0^{\circ}$ (a) dan latitude $2^{\circ}$ (b).

Angin zonal yang bergerak searah dengan sumbu $x$ positif bernilai positif dan disebut dengan angin baratan sedangkan angin zonal yang bergerak searah dengan sumbu $\mathrm{x}$ bernilai negatif dan disebut dengan angin timuran. Gambar 5a merupakan diagram Hovmoller untuk latitude $0^{\circ}$. Dapat dilihat bahwa angin baratan di wilayah Indonesia (area di antara garis putusputus) menguat mulai akhir tahun 2015 hingga pertengahan 2015 dan area pertemuan angin baratan dan timuran bergeser ke Timur di Samudera Pasifik. Dapat dilihat pula pada Gambar 5b bahwa angin baratan menguat pada periode Maret 2015 hingga Oktober 2015 dan daerah pertemuan angin terjadi di Samudera Pasifik bagian Timur. Angin Baratan mulai melemah di akhir 2015. Pusat tekanan rendah bergeser ke Samudera Pasifik bagian Barat.

\subsection{Indian Ocean Dipole (IOD)}

Indian Ocean Dipole (IOD) merupakan kondisi interaksi laut-atmosfer yang terjadi di Samudra Hindia Tropis, dimana terjadi beda temperatur permukaan laut antara Samudera Hindia tropis bagian Barat atau pantai Afrika Timur dengan Samudera Hindia tropis bagian Timur atau pantai Barat Sumatera. Indeks IOD (Indian Ocean Dipole) atau Indeks DM (Dipole Mode) didefinisikan sebagai beda anomali temperatur permukaan laut Samudera Hindia bagian Timur dengan Samudera Hindia bagian Barat, dimana nilai indeks IOD $>0.4$ digolongkan 
sebagai IOD $(+)$ dan indeks IOD $<-0.4$ digolongkan sebagai IOD (-). IOD (+) artinya temperatur permukaan laut di pantai timur Afrika lebih tinggi daripada suhu permukaan laut di pantai Barat Sumatera, sebaliknya adalah IOD (). Dengan demikian IOD (+) merupakan fase dingin laut pantai Barat Sumatera, sehingga konveksi melemah, sebaliknya IOD (-) adalah fase panas laut pantai Barat Sumatera sehingga konveksi menguat yang mengakibatkan adanya peningkatan curah hujan di wilayah Barat Indonesia selama fase IOD (-) tersebut.

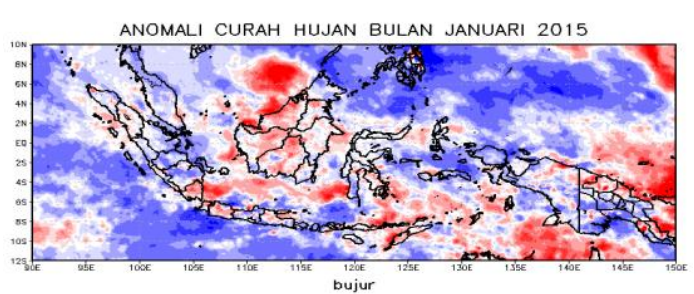

ANOMALI CURAH HUJAN BULAN MARET 2015

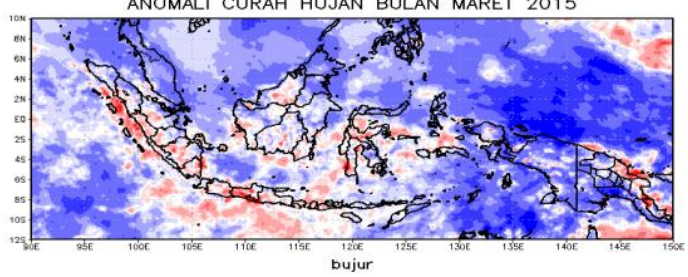

ANOMALI CURAH HUJAN BULAN MEI 2015

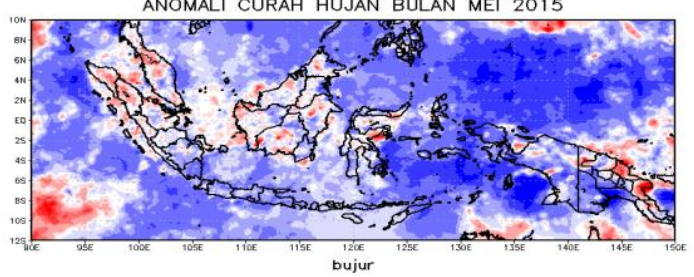

ANOMALI CURAH HUJAN BULAN JULI 2015

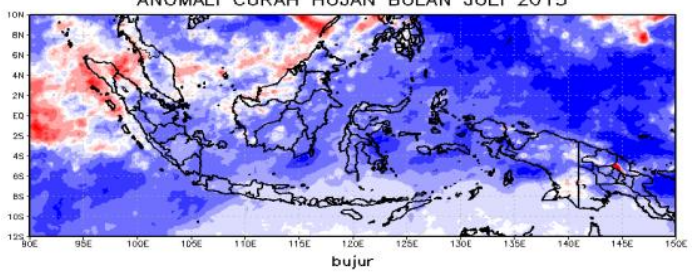

ANOMALI CURAH HUJAN BULAN SEPTEMBER 2015

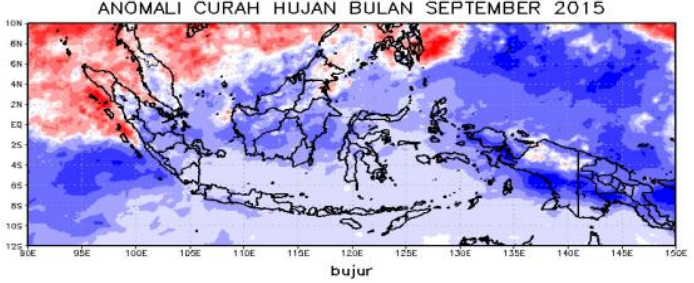

ANOMALI CURAH HUJAN BULAN NOVEMBER 2015

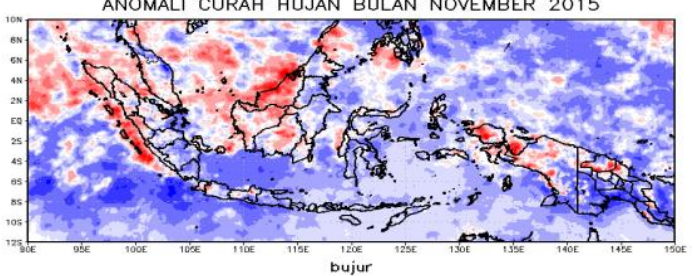

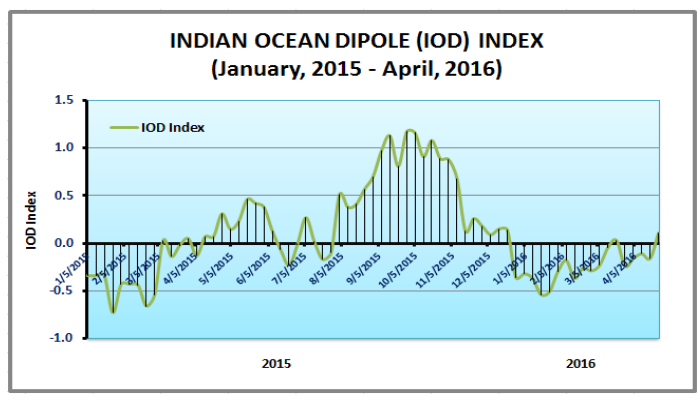

Gambar 6. Grafik Indian Ocean Dipole Index (Januari 2015 - April 2016).

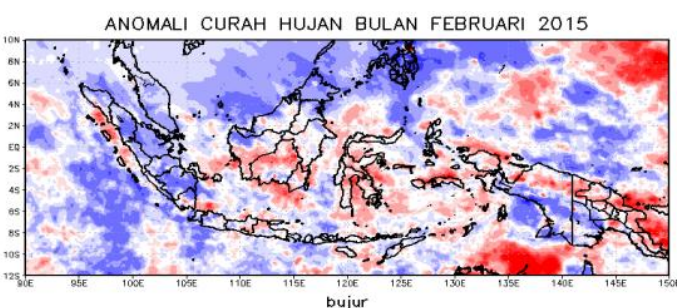

ANOMALI CURAH HUJAN BULAN APRIL 2015

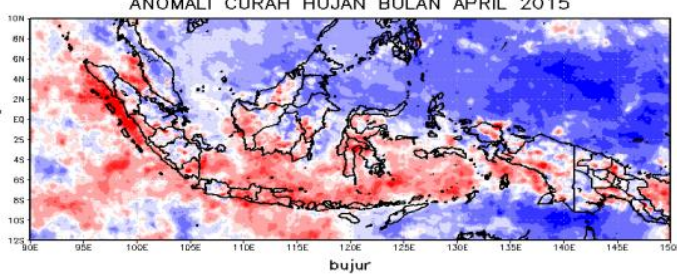

ANOMALI CURAH HUJAN BULAN JUNI 2015

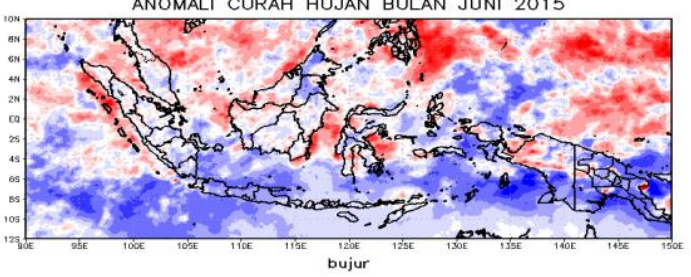

ANOMALI CURAH HUJAN BULAN AGUSTUS 2015

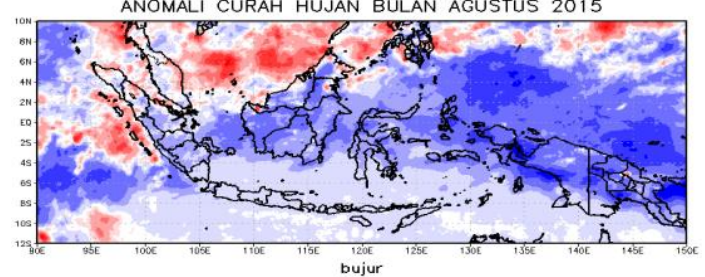

ANOMALI CURAH HUJAN BULAN OKTOBER 2015

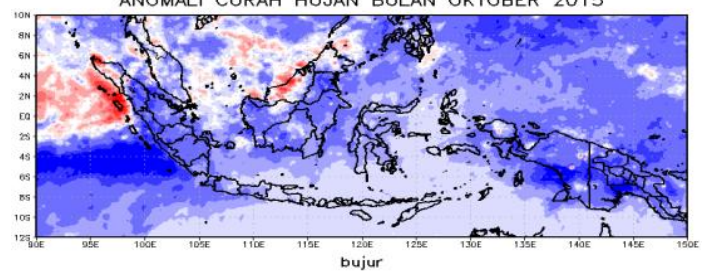

ANOMALI CURAH HUJAN BULAN DESEMBER 2015

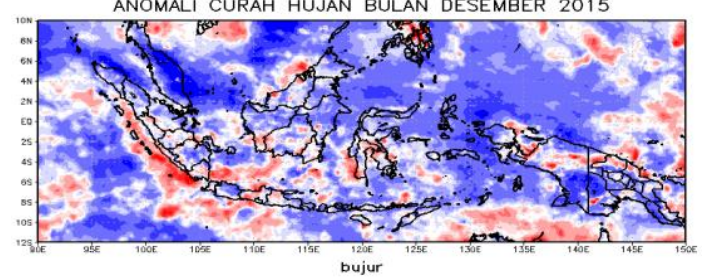

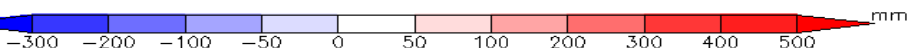

Gambar 7. Peta anomali curah hujan wilayah Indonesia bulan Januari-Desember 2015. 
Gambar 6. merepresentasikan grafik nilai Indian Ocean Dipole (IOD) Index dari bulan Januari, 2015 hingga April 2016. Berdasarkan grafik tersebut dapat diketahui bahwa pada bulan Januari hingga Maret 2015 IOD Index masih relatif pada posisi negatif $(-)$ artinya walaupun sudah ada gejala fenomena El Nino sejak awal Tahun 2015, akan tetapi pembentukan awan di wilayah Indonesia terutama di wilayah Indonesia bagian Barat masih terbantu dengan adanya fase panas di perairan laut sebelah Barat Sumatera sehingga di wilayah Indonesia bagian Barat masih banyak curah hujan walaupun di bawah intensitas rata-rata curah hujan historisnya. Akan tetapi mulai bulan Juli 2015 IOD Index sudah relatif pada posisi positif (+) dan puncaknya pada akhir bulan September 2015 IOD Index mencapai (+) 1.17 yang mengindikasikan temperatur permukaan laut di pantai Timur Afrika lebih tinggi daripada suhu permukaan laut di pantai Barat Sumatera, sehingga konveksi di pantai Barat Sumatera akan melemah dan hal tersebut akan semakin memperparah efek dari fenomana El Nino yang ada pada level kuat terutama pada bulan Juli hingga Oktober 2015. Pada Bulan Desember 2015 IOD Index berangsur menurun dan awal Tahun 2016 IOD Index telah ada pada posisi negatif (-), hal tersebut akan membantu dalam peningkatan curah hujan di sebagian besar wilayah Indonesia walaupun dari bulan Januari hingga Maret 2016 El Nino masih dalam level kuat.

\subsection{Anomali Curah Hujan}

Bergesernya pusat tekanan rendah karena melemahnya angin timuran pada sirkulasi Walker mempengaruhi intensitas curah hujan khususnya di wilayah Indonesia. Meningkatnya jumlah titik api di sejumlah wilayah di Sumatera dan Kalimantan disebabkan oleh berkurangnya intensitas curah hujan yang menyebabkan terjadinya kekeringan. Data curah hujan yang digunakan pada kajian ini adalah data curah hujan yang berasal dari satelit Tropical Rainfall Measuring Mission (TRMM) dati tahun 2009 hingga 2015 dengan resolusi spasial $0.1^{\circ} \times 0.1^{\circ}$ dan resolusi temporal satu jam. Anomali curah hujan yang terjadi dapat dilihat dari data rata-rata bulanan historisnya dan disajikan pada Gambar 7. Anomali negatif menunjukkan curah hujan bulanan yang lebih kecil dari curah hujan rataratanya. Hal ini terlihat pada Anomali Curah Hujan bulan Juli hingga Oktober 2015, curah hujan bulanan di wilayah Sumatera dan Kalimantan menunjukkan anomali negatif.

Terjadinya anomali negatif pada curah hujan di wilayah Sumatera dan Kalimantan akibat ENSO menyebabkan terjadinya kekeringan dan meningkatnya jumlah titik api.

\subsection{Analisis Jumlah dan Sebaran Titik Api}

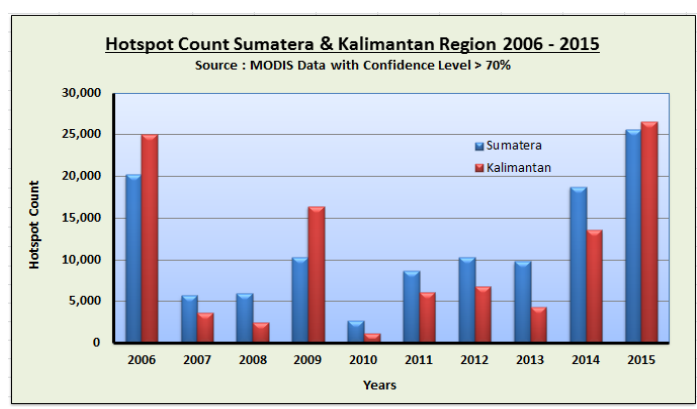

Gambar 8. Grafik jumlah titik api di wilayah Kalimantan dan Sumatera tahun 2006 - 2015.

Berdasarkan Grafik jumlah titik api selama sepuluh tahun terakhir dari tahun 2006 hingga tahun 2015 yang direpresentasikan pada Gambar 8 dapat diketahui bahwa kejadian El Nino tahun 2015 hingga level kuat telah sangat berpengaruh terhadap peningkatan jumlah titik api di Wilayah Sumatera dan Kalimantan, Indonesia. Dimana berdasarkan Citra Satelit MODIS jumlah titik api di Wilayah Sumatera dan Kalimantan dengan tingkat kepercayaan diatas $70 \%$ pada tahun 2015 merupakan yang tertinggi selama 10 tahun terakhir, dengan jumlah titik api lebih dari 50.000 titik api.

Peningkatan jumlah titik api di wilayah Sumatera dan Kalimantan pada tahun 2015 untuk tiap bulannya juga sangat berhubungan dengan anomali curah hujan bulanan di wilayah Sumatera dan Kalimantan pada tahun 2015. Dimana pada analisis anomali Curah Hujan pada pembahasan sebelumnya dapat diketahui bahwa pada Tahun 2015 anomali curah hujan negatif pada tingkat ekstrim di sebagian besar wilayah Indonesia mulai terjadi pada bulan Juli hingga Oktober 2015.

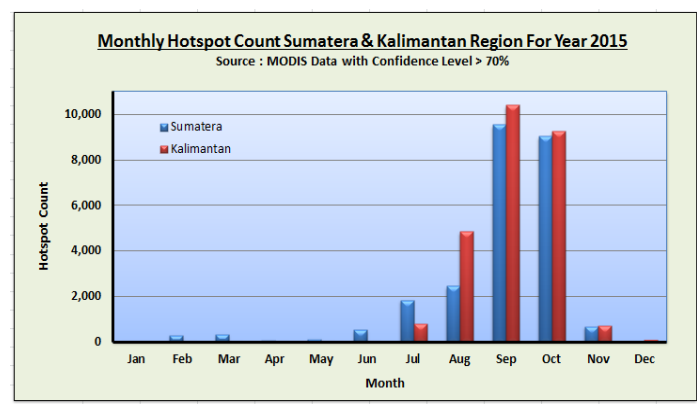

Gambar 9. Grafik jumlah titik api bulanan di wilayah Kalimantan dan Sumatera tahun 2015.

Berdasarkan Gambar 9 yang merepresentasikan grafik jumlah titik api bulanan di Wilayah Sumatera dan Kalimantan tahun 2015 dapat diketahui bahwa peningkatan jumlah titik api di kedua wilayah tersebut mulai meningkat dengan pesat sejak bulan Juli dan terus meningkat hingga bulan Oktober 2015. Sedangkan pada bulan November 2015 jumlah titik api sudah menurun secara drastis seiring dengan peningkatan jumlah curah hujan di sebagian besar wilayah Indonesia dibandingkan 

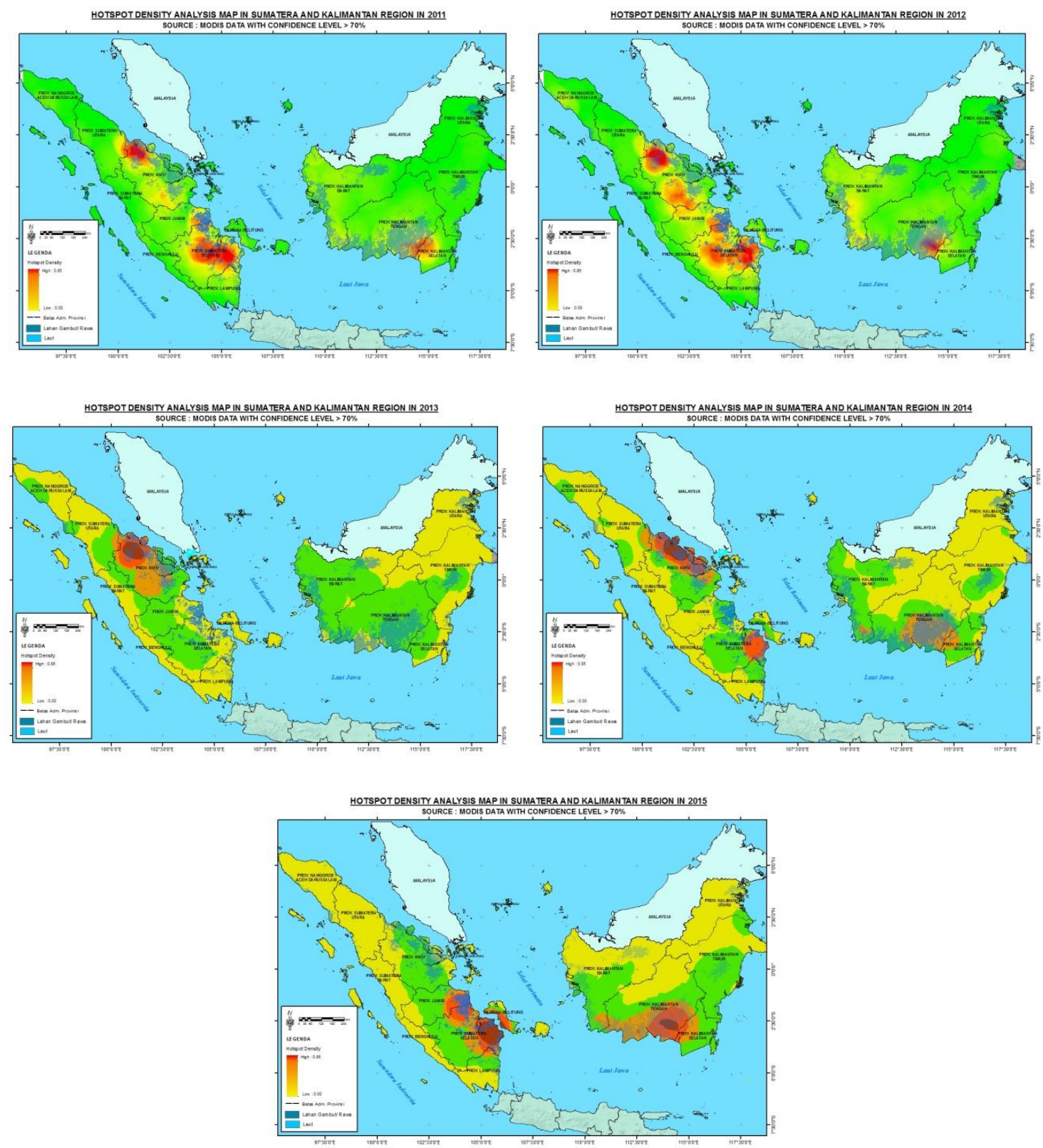

Gambar 10. Peta analisis kerapatan titik api di wilayah Sumatera dan Kalimantan tahun 2011-2015.

dengan bulan-bulan sebelumnya dikarenakan mulai meningkatnya suhu permukaan laut di wilayah perairan laut Indonesia dan pantai Barat Sumatera.

Sedangkan berdasarkan analisis kerapatan titik api di wilayah Sumatera dan Kalimantan selama lima tahun terakhir dari tahun 2011 hingga 2015 yang direpresentasikan pada Gambar 10 dapat diketahui bahwa keberadaan titik api pada tahun 2011 hingga 2012 di wilayah Sumatera terkonsentrasi di Provinsi Riau dan Sumatera Selatan dan di wilayah Kalimantan terkonsentrasi di daerah bagian Selatan perbatasan antara Provinsi Kalimantan Tengah dan Kalimantan Selatan.

Pada tahun 2013 titik api di wilayah Sumatera lebih terkontrasi berada di Provinsi Riau dan di wilayah Kalimantan titik api lebih terkonsentrasi di Provinsi Kalimantan Tengah. Sedangkan pada tahun 2014 titik api di wilayah
Sumatera terkontrasi berada di Provinsi Riau juga di Provinsi Sumatera Selatan dan di wilayah Kalimantan titik api lebih terkonsentrasi di Provinsi Kalimantan Tengah. Untuk tahun 2015 saat terjadi fenomena EI Nino pada level kuat titik api di wilayah Sumatera dapat diketahui lebih terkonsentrasi di Provinsi Sumatera Selatan dan untuk wilayah Kalimantan pada tahun 2015 titik api juga terkonsentrasi di Provinsi Kalimantan Tengah.

\section{KESIMPULAN}

Berdasarkan parameter NINO 3.4 SST Index dan Southern Oscillation Index dapat diketahui bahwa pada tahun 2015 telah terjadi fenomana El Nino pada level kuat.

Berdasarkan analisis zonal wind juga dapat diketahui bahwa pada tahun 2015 telah 
terjadi pelemahan sirkulasi walker sehingga pusat tekanan rendah berpindah dari Samudera Pasifik bagian Barat ke Samudera Pasifik bagian Timur yang mengindikasikan adanya Fenomena El Nino pada tahun 2015 tersebut.

Dari Parameter Indian Ocean Dipole (IOD) Index dapat diketahui bahwa mulai bulan Juni 2015 IOD Index ada pada nilai positif (+) dan puncaknya pada akhir bulan September 2015 dimana IOD Index mencapai (+) 1.17 yang mengindikasikan temperatur permukaan laut di pantai Timur Afrika lebih tinggi daripada suhu permukaan laut di pantai Barat Sumatera sehingga konveksi di pantai Barat Sumatera akan semakin melemah dan hal tersebut akan semakin memperparah dampak dari fenomena El Nino di Indonesia.

Bergesernya pusat tekanan rendah karena melemahnya angin timuran pada sirkulasi Walker dan IOD Index ada pada nilai positif telah mempengarui penurunan intensitas curah hujan (anomali negatif) di sebagian besar wilayah Indonesia khususnya dari bulan Juli hingga Oktober 2015.

Berdasarkan analisis jumlah titik api dapat diketahui bahwa jumlah titik api di wilayah Kalimantan dan Sumatera pada tahun 2015 merupakan yang tertinggi selama sepuluh tahun terakhir, dimana peningkatan titik api pada secara tajam pada tahun 2015 terjadi dari bulan Juli hingga Oktober dengan konsentrasi keberadaan titik api di Provinsi Sumatera Selatan dan Kalimantan Tengah.

\section{DAFTAR PUSTAKA}

Ardhitama, A. (2013). Model Simulasi Prakiraan Curah Hujan Bulanan pada Wilayah Riau dengan Menggunakan Input Data SOI, SST, NINO 3.4, dan IOD. Jurnal Sains \& Teknologi Modifikasi Cuaca, 14(2), 95-104.

Bahri, S. (2002). Kajian Penyebaran Kabut Asap Kebakaran Hutan dan Lahan di Wilayah Sumatera Bagian Utara dan Kemungkinan Mengatasinya Dengan TMC. Jurnal Sains \& Teknologi Modifikasi Cuaca. 3(2), 99104.

Danoedoro, P. (1996). Pengolahan Citra Digital, Teori dan Aplikasinya. Yogyakarta: Fakultas Geografi UGM.
Estiningtyas, W., Ramadhani, F., Aldrian, E. (2007). Analisis Korelasi Curah Hujan dan Suhu Permukaan Laut Wilayah Indonesia, Serta Implikasinya untuk Prakiraan Curah Hujan (Studi Kasus Kabupaten Cilacap). Jurnal Agromet Indonesia, 21(2), 46-60.

Fadholi, A. (2013). Studi Dampak El Nino dan Indian Ocean Dipole (IOD) Terhadap Curah Hujan di Pangkalpinang. Jurnal IImu Lingkungan Program Pascasarjana UNDIP, 11(1), 43-50. doi: 10.14710/jil.11.1.43-50

Harijono, S.W.B. (2008). Analisis Dinamika Atmosfer di Bagian Utara Ekuator Sumatera pada Saat Peristiwa El-Nino dan Dipole Mode Positif Terjadi Bersamaan. Jurnal Sains Dirgantara, 5(2), 130-148.

Jensen, J.R. (2005). Introductory Digital Image Processing: A Remote Sensing Perspective, $3^{\text {rd }}$ ed. Sydney: Pearson Prentice Hall.

Martono. (2015). Dampak El Nino dan Indian Ocean Dipole 1997-1998 Terhadap Intensitas Curah Hujan di Wilayah Pantai Utara dan Pantai Selatan Jawa. Prosiding Pertemuan IImiah XXIX HFI Jateng \& DIY 2015. Yogyakarta.

Mulyana, E. (2002). Pengaruh Dipole Mode Terhadap Curah Hujan di Indonesia. Jurnal Sains \& Teknologi Modifikasi Cuaca, 3(1), 39-43.

Sutanto. (1994). Penginderaan Jauh-Jilid 2. Yogyakarta: Gadjah Mada University Press.

Tjasyono, B., Lubis, A., Juaeni, I., Ruminta, Harijono, S.W.B. (2008). Dampak Variasi Temperatur Samudera Pasifik dan Hindia Ekuatorial Terhadap Curah Hujan di Indonesia. Jurnal Sains Dirgantara, 5(2), 113.

Tongkukut, S.H.J. (2011). El Nino dan Pengaruhnya Terhadap Curah Hujan di Manado Sulawesi Utara. Jurnal Ilmiah Sains, 11(1), 102-108.

World Meteorological Organization. (2015). WMO Statement in The Status of The Global Climate in 2015. Switzerland: World Meteorological Organization (WMO).

Wyrtki, K. (1961). Physical Oceanography of Southeast Asean Waters. Naga Report I. 2. California: The University of California. 